\title{
COMPETITIVENESS OF COMPANIES IN THE COMPETITIVE ENVIRONMENT - THE ESSENTIAL QUESTION OF PERFORMANCE MANAGEMENT
}

\author{
Elena Loredana COMĂNESCU, Ioana Antoaneta PONEA (RADU), \\ Cornelia PETRE (STAN), Maria Georgiana PONEA \\ „Valahia” University of Târgovişte, Romania \\ lory_ela@yahoo.com,radoo_oana@yahoo.com,stancornelia1984@yahoo.com, \\ Georgia_ponea@yahoo.com
}

\begin{abstract}
Competitiveness is the ability of the company to compete with commodities that meet the needs of customers in terms of price, quality and diversity. It is possible to the extent that the firm has a competitive advantage and whose affirmation has its source in the internal conditions of the firm and which the economic environment, first of all the competitive one, can favor. In the field of management, the strategy is the art of conducting a set of devices in order to achieve a goal. M. Porter argues that the strategy is "the art of building competitive advantages that can be defended over a long period of time."
\end{abstract}

\section{Keywords: competitiveness, competitive strategies, innovation, efficiency}

\section{General features}

Competitiveness is a complex concept that expresses a firm's ability to survive in the conditions of competition, by proving products and services that meet high quality standards at competitive prices, both nationally and internationally, in relation to the possibilities and performance of other companies. The term competitiveness associated with a company suggests safety, efficiency, quality, high productivity, adaptability, success, modern management, superior products, optimal costs.

The assessment of the company's competitiveness can be done by analyzing the economic efficiency in relation to other competitors on the market. In practice, the competitiveness of a company is analyzed in terms of two indicators: the yield obtained and the impact of the products/services on the market.

Experience shows that the yield is regarded as a means of ensuring the profitability of a business (development and achievement of the established economic and social objectives) and not as a goal of the enterprise.

Therefore, the basic objective of the enterprise is to satisfy the client and society as a whole, but profit should not be neglected considering that it constitutes an indicator of the company's performance on its competitiveness. It must be regarded as a consequence of the results obtained by the undertaking, as a reward for the success in a competitive market.

At the same time, the impact of the products/services of a firm on a market underlines the performance of the enterprise by the adaptation of the products or services to the needs and requirements of customers. The undertakings' goal is to satisfy customer's requirements in order to achieve an important market share and profits required for extending their business. Studying the needs of the customers is an 
essential condition for delivering quality products and services, so that a strategy based on quality determine the progress in achieving the company's competitiveness.

A firm is competitive when it succeeds in achieving results comparable to or better than those of its competitors. This is achieved when the conditions available (factors of production, management and marketing, financial resources, technical and creative resources, etc.) become a durable advantage over the competitor (in terms of cost, diversity, quality and costeffectiveness), providing normal dividends to shareholders, self-financing and laborrelated resources, correlated with productivity. Therefore, competitiveness depends to a large extent on the internal conditions of the enterprise, which express all the components and functions that define it.

\section{Factors that ensure the competitiveness of the company:}

A company is competitive when it has the ability to face competition through commodities and services that can meet customer requirements (price, quality, innovation and diversity). Competitiveness is only possible if the firm has this competitive advantage, and its assertion in the market has its essence in providing value for consumers, as well as in the promotion strategies that the competitive environment can favor or prevent. Competitive success will be achieved if either products (services) of the same quality are offered at a lower price than the market or by offering products (services) of the same price, of better quality in relation to the market.

Riposte of competitiors occurs sooner or later, rebalancing the competitive situation by:

- quick reaction, lowering the price;

- slow reaction, improving quality.

In addition to the price and quality factor, it appears as the main factor the price/quality ratio. Like the other two main factors, this is eliminating under the following aspects:
- if the firm produces a good (service) that can satisfy a certain need but requires a price that the customer on a particular market can not pay, the firm is eliminated from the market by the price factor;

- if the company requires an acceptable, even convenient, price on a product (service) which does not fully satisfy a particular need (eg a product that breaks off the second use), the company is eliminated from the market by the quality factor;

- if at a certain value of an enterprise it can not be profitable but demanding a higher price than the market price for that date, or at a selling price given can only produce profit than by subtrating the quality of the market for the products sold at that price, in this case the firm is eliminated from the market by the factor price/quality ratio, even if the price it is asking for is not so great that customers can not pay.

Other factors of competitivity are the cost and profit. The cost it is related to the selling price, which is determined by the market balance. The profit is the difference between the selling price and the cost. In a dynamic perspective we can not ignore a main factor, resulting from the combination of the two factors mentioned: the cost/benefit ratio.

An undertaking that reach high profits is not efficient if done with very high cost; it will crack when a competitor in the same dimensions will be able to reduce the disproportionate costs.

A less common case is a small profitmaking company and, at the same time it operates with abusive low costs. From a statistical perspective, this firm has an increased competitiveness. Such a firm ensures profit margin by reducing to a maximum the costs, including development costs (investment, marketing, etc.). It achieves a reasonable performance now, but it sacrifices its future performance. So in a dynamic perspective, such a firm is not competitive because the cost/ profit ratio is too high. It will be a danger in competition with another firm that has higher and well- 
structured costs (with an important component of development expenses in the cost structure), but which has a good cost/profit ratio that will enable it to supply such expenditure of development.

Increasing competitiveness at the firm level is a concern of the private entrepreneur, without excluding those who manage public interests. So, we can assume that the creative factor of competitiveness is micro level, being supported at macroeconomic level by empowered institutions and policy makers through support research and innovation, promoting healthy policies to reduce the budget deficit, a better targeting spending (infrastructure improvement, investment in human capital) and fiscal sustainability.

\section{The analysis of the competitive environment}

Michael Porter's competitive market model has quickly become a world-wide benchmark in literature and managerial practice for his synthetic character, and because he clearly identify the most intensive forces, common to the markets specific to all industries, despite the appreciable differences that exist at the same time between markets.

Competitive forces within an industry are as follows:

1. Rivalry between existing competitors.

2. Potential Entrants.

3. The pressure exerted by substitutes.

4. Customer negotiation capacity.

5. Negotiating capacity of suppliers.

A company must constantly make a comparison between products, prices, distribution channels and promotions with those of its competitors, the knowledge and understanding the needs of its customers it is no longer sufficient.

Successful companies must always have information about their competitors, they need to know who they are, what strategies they use, what goals they have, what strengths and weaknesses they have. All this information is used by companies to know the advantages and disadvantages that they have in the struggle with their competitors.

Rivalry between existing competitors takes the form of price competition, introducing new products, improving services and warranties offered to buyers after the sale, etc., all in order to obtain advantageous positions.

It is very important for an enterprise to identify first of all which its competitors are because the actual and potential competitors are very large and this is likely to lose more customers due to new technologies and of its competitors in the affirmation over those already known by latter. In this respect, Kotler identifies four levels of competition:

1. The Competition Brand: Competitors are those who offer similar products or services at almost same prices to the same categories of consumers.

2. The Competition at the level of the industry: A company considers another company as a competitor if it provides the same product or category of products.

3. Formal competition: The company considers competitors all companies that offer products designed to meet the same needs.

4. Generic competition: Competitors are represented by all firms struggling for the same income of consumers.

\section{Types of strategies:}

\subsection{Managerial strategies}

The competitive strategy of the firm needs to adapt quickly to any change, so that it is necessary to monitor closely the market, maintaining the offensive strategy and defense of results, adapting the competitive harassment strategy based on reactivity to any attempts by competitors to erode their position on the market.

Strategies are proven to be benefical to the enterprise only if they are judiciously established, implemented correctly, if pursued consistently, and if they ensure that the competitive advantages for the firm are maintained in perspective, allowing for a better positioning on the market, specific to the field in which they operate. 
The competitive advantages of a company are numerous and diverse and may consist in: large or very large size of the firm; providing products/services at the lowest prices or at the highest quality level; domination of a specific segment of the market (a specific geographical area, a specific group of buyers) or providing of the highest overall value for the price received, which represent a judicious combination and particularly attractive for the buyer through high quality, affordable price, appropriate service [1].

The realities of the competitive business environment have demonstrated that the common element of competitive advantages mentioned, regardless of the strategy followed for their acquisition and maintenance, leads to the creation of a viable segment and large enough to attract customers interested in purchasing the products/services offered by the firm, as they are perceived as having a superior overall value.

Practice has shown that, offensive strategies are those through which the companies are trying to have and to maintain the initiative on a particular plan of competition by front attacks (advertising, innovation) or encirclement (placing similar products at a lower price on the market), thus forcing the other competitors to dispel their defense resources and act defensively. In addition, in order to successfully use an offensive strategy and to create on this basis a competitive advantage, the company must have a series of indispensable capabilities required to undertake, the most efficient and different strategic actions compared to the main rivals to succeed annihilation; to take advantage at any time of the weaknesses of competitors and their inability to react; to have the power to carry out the first movement in order to gain the right of privilege in front of competitors; to be able to respond to counterfeiters that can not be easily limited by other competitors, thereby creating them significant difficulties in attempting to follow a similar strategy. Having regard the preponderant capabilities, the agent (company) can engage in one of the following strategies: the final attack on competitors' strengths or weaknesses (concerns the quality of products/services, low resources and lack of promotional activities); simultaneous attack on multiple fronts; offensive bypassing the strengths of competing firms; the "guerrilla" offensive (attack at the right time, when the opponent faces financial difficulties or lack of forced competitiveness), positioning strategy aimed at attracting loyalty for a product similar to that of the competition, as well as the privileged strategy of winning rights or benefits.

In order to gain a competitive advantage, the company must initiate a strategic planning and a more extensive research of target markets for identifying potential customers, but also to identify competition, with its advantages and disadvantages, so as to be able to differentiate itself from this by offering consumers value and maintaining market share. In this respect, the reason for the business is, of course, to make available quality goods and services at reasonable prices [2], but at the same time, higher prices should justify their value in relation to consumer claims.

The related issues demonstrate that the implementation of certain strategies means the firm's achievement of the competitive advantage, which is not easy to defend because it generally stimulates the way in which the competition takes place. In many sectors of activity there are companies that have a long tradition in national and international markets. These production entities or services are able to compete internationally because they have an advantage over competition in which three types are identified, as Porter [3] appreciates:

1) the competitive advantage based on minimum unit costs for the supply of products or the provision of equivalent services; 
2) the competitive advantage based on the strategy of differentiation (oriented towards product uniqueness) or diversification;

3 ) the competitive advantage related to a strategy of focusing on a certain segment of the market by sales in small quantities, with the objective of dominating marginalized customers that can respond to the degree of differentiation and the appropriate costs according to their claims.

Holding a competitive advantage as a company is a very important thing, but the long-term maintenance depends on its source, the effort for the regeneration and deeping of the competitive advantage, the quality of the business environment, and the reduction in dependency on the circumstances that can provide temporary competition advantages.

The competitive advantage has a number of determinants that are in a relationship of interdependence, as shows us the Porter's model [4]. These are the production factors based on: investment and employment; the demand of the market; the competitive environment in related industries; strategies and competitive companies. In parallel, state intervention can influence these determinants of the competitive environment.

Thus, innovation, affordable prices and faster services can determine the difference when it comes to attract customers and earning profits, and increasing competitiveness opens the horizon of progress and permanent search for getting success in business.

\subsection{Competitive strategies}

There is no universally valid strategy. Each firm needs to know which strategy is proper for it, taking into acount the company's position in its field of activity, the goals it has, opportunities and resources. Even within a company, more strategies are required, depending on the company's activities or of products made. For example, Johnson \& Johnson uses a strategy for dominant brands, and another strategy for new health care products that require a high technology.

\section{Conclusions: strong competition, increased competitiveness}

At the level of the undertaking, competitiveness refers mainly to the ability of companies to learn, to adapt quickly to market conditions and to innovate. Nationally, competitiveness can be regarded as a means of improving the standards of living in terms of optimal use of limited resources. In the early 1990s, referring to competitiveness, Paul Krugman claimed in a famous Foreign Affairs article that companies compete with each other, not national states. To a certain extent, his claim can not be challenged. But globalization and market imperfections make public politics to play an important role in the economy, and companies have to seriously consider the coordinates of the space in which they operate. Thus, competitiveness, in any of its forms, it is strongly influenced by public policies, such as taxation, competition policy, orientation of public finances, etc.

Restrictive competition rules and legal rules have a negative impact on competitiveness as it leads, first of all, to a slowdown in the technological upgrading process. On the other hand, national competition rules, harmonized with Community rules, can have the beneficial effect of creating fair conditions in the market for all economic actors.

The existence of a solid competitive environment, to encourages efficient companies at the expense of inefficient ones, may represent an incentive competitiveness through the following three levers:

- Ensuring an efficient allocation of resources;

- Boosting companies to organize their activity in an efficient manner;

- Rising innovation activity.

The more open markets are for competition, the benefits to competitiveness are more visible. 


\section{References}

[1] Corneliu Russu, Management strategic, Editura All Beck, Bucureşti, 1999, p. 201

[2] Ioan Popa, Radu Filip, Management internaţional, Bucureşti, Editura Economică, 1999, p. 257

[3] Porter Michael, Competitive Advantage, Free Press, New York, 1985, p. 3

[4] Porter Michael, „The Five Competitive Forces That Shape Strategy”, Harvard Business Review, 2008, p. 79-93; http://www.asec-sldi.org/dotAsset/292822. 